\title{
Editorial
}

\section{Academic integrity and plagiarism: The new regulations in India}

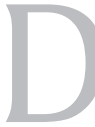
ishonesty in research and publication, be intentional or not, goes much beyond an act of delinquency. The consequences can be dire and far-reaching. Regardless of economic and academic progression, plagiarism remains to be aglobal concern. The publishing houses, editors and authors are bound by the publication ethics, yet effective retributive tools remain scattered and unable to curtail the epidemic.

To comprehend 'what constitutes plagiarism' is a major obfuscation among young researchers, resulting in unintentional plagiarism. Recently, the Government of India notified new regulations"Promotion of Academic Integrity and Prevention of Plagiarism in Higher Educational Institutions"which were adopted by the University Grant Commission (UGC). ${ }^{[1]}$ The document published in The Gazette of India on July 31, 2018, defines plagiarism and the means to deal with it. According to the new regulations, plagiarism is "the practice of taking someone else's work or idea and passing them as one's own."

The regulation further explains "(i) all quoted work reproduced with all necessary permissions and/or attribution, (ii) all references, bibliography, table of content, preface and acknowledgements, (iii) all generic terms, laws, standard symbols and standard equations" are not considered plagiarism. Submitted manuscripts are routinely screened for the similarity index employing the software such as iThenticate ${ }^{\circledR}$, Turnitin ${ }^{\circledR}$ and so on. This screening identifies similar texts from already published material and summates the total percentage. The present regulation relies on this percentage to quantify the plagiarism and to decide on the quantum of penalty.

However, there are drawbacks in this scrutiny; not all percentage of similarity is necessarily plagiarism. ${ }^{[2]}$ The report needs to be interpreted carefully. The text describing similar methodology or common clinical terms is likely to be similar. Further, manual intervention is needed by the assessor to exclude quotations and bibliography. Thus, to arbitrate on the "acceptable percentage of similarity" for a manuscript needs critical analysis. Under the new guidelines up to $10 \%$ similarity is acceptable and terms it as minor or Level 0 . The drawback is, this minor similarity could be a significant plagiarism if taken from a single source. The guidelines further quantify the degree of plagiarism as Level 1: Similarities above $10 \%$ to $40 \%$, Level 2: Similarities above $40 \%$ to $60 \%$, Level 3: Similarities above $60 \%$.

Based upon the level, students or researchers submitting their script face penalty. The penalty ranges from re-submitting revised script for Level-1, debarring for one year for Level-2 and to cancellation of students' registration from the enrolled program in Level-3 offense. For the faculty, plagiarism beyond $10 \%$ similarities mandates withdrawal of manuscript. At $40-60 \%$ level they are debarred from supervising a master's program for two years and lose an increment for one year. If it exceeds $60 \%$, loss of increment for two years and not allowed as supervisor for 3 years is the penalty.

What do these guidelines mean to the publishing houses and the journal? Plagiarism in any form or any percentage is unacceptable and non-negotiable. A plagiarized manuscript which cannot be rectified faces inevitable rejection. Further, if already published, retraction is obligatory. The appropriate action that needs to be initiated against the authors are yet to be addressed satisfactorily. Debarring the author does not restrain from future submission and it is practically impossible to screen a submission as co-author. Several journals demand authors' scientific profile and have made mandatory to share ORCID or Researchgate IDs. ORCID provides a unique 16-digitID, which is a digital profile and affiliation of the researcher. Thus, with some checks in place, authors are prevented from creating duplicate profiles. With the new regulations, the publisher can notify the author's affiliated institution and bring them under the purview of the law of the land and regulations. The mechanism to 
address any such complaint is elaborated and falls under the purview of Institutional Academic Integrity Panel (IAIP).

Though the regulation is a welcome step it has limitations and drawbacks. It appears to address only the "copy-paste" act by relying heavily on the similarity index, ignoring various forms of dishonesty which include self-plagiarism, wrong citation, data manipulation, photo plagiarism and so on. An innovative idea or publication when reproduced by paraphrasing without citing the source can escape similarity check and authenticates the publication. Percentage below $10 \%$ need not be ignored. Further, plagiarism in any form or level should be discouraged in absolute terms. Grading them is not a good idea and gives a sense of impunity to the perpetrators.

Plagiarism is considered immoral act and not perceived as a crime. Though there is no separate Plagiarism Act in India, it is governed by the section 57,63 and 63 (a) of the Copyright Act. Copyright violation is using the authors' work without permission, whereas in plagiarism, it is used without attribution. Under these sections, plagiarism can attract imprisonment from 6 months to 3 years. ${ }^{[3]}$

Tens of thousands of research work are submitted every year to HEI from postgraduates as a thesis or dissertation. Creating awareness and education on scripting a good manuscript are imperative. Institutions and authors should have an easy access to good screening software for manuscripts. The responsibility of submitting an unblemished manuscript rests with the authors, researchers and guides. Senior authors cannot absolve themselves from the responsibilities. The final manuscript must be checked by senior author and figure out any change in language style which is possibly not author'sown. It is essential that all co-authors must contribute and go through the manuscript, and thus rectify all possible issues. Any complacence from authors over a negligent manuscript may have serious consequences on reputation, academic integrity and career, which is entirely avoidable.

\section{Dinesh Kadam}

Editor IJPS, Professor and Head, Department of Plastic and Reconstructive Surgery, A J Institute of Medical Sciences and A J Hospital and Research Centre, Mangalore,

Karnataka, India

E-mail: drkadam@yahoo.co.in

\section{REFERENCES}

1. The Gazette of India: Extraordinary [PART III-SEC. 4]; 31 July, 2018. Available from: http://www.egazette.nic. in/WriteReadData/2018/187871.pdf. [Last accessed on 2018 Aug 23].

2. CrossCheck Plagiarism Screening: Understanding the Similarity Score; 11 Aug, 2011. Available from: http://www.ithenticate. $\mathrm{com} /$ plagiarism-detection-blog/bid/63534/CrossCheckPlagiarism-Screening-Understanding-the-Similarity-Score\#. W80loGgzblU. [Last accessed on 2018 Aug 24].

3. Pandey A. Laws Relating to Plagiarism in India; 11 June, 2017. Available from: https://www.blog.ipleaders.in/plagiarism-lawindia/. [Last accessed on 2018 Aug 24].

This is an open access journal, and articles are distributed under the terms of the Creative Commons Attribution-NonCommercial-ShareAlike 4.0 License, which allows others to remix, tweak, and build upon the work non-commercially, as long as appropriate credit is given and the new creations are licensed under the identical terms.

\begin{tabular}{|l|l|}
\hline \multicolumn{2}{|c|}{ Access this article online } \\
\hline Quick Response Code: & Website: \\
\hline
\end{tabular}

How to cite this article: Kadam D. Academic integrity and plagiarism: The new regulations in India. Indian J Plast Surg 2018;51:109-10. 